\title{
EFFECT OF HEMICHOLINIUM-3 ON CHOLINE DISTRIBUTION IN VIVO IN THE CANINE CAUDATE NUCLEUS*, $\dagger$
}

\author{
Marcus V. Gomez, Edward F. Domino and Otto Z. Sellinger \\ The Michigan Neuropsychopharmacology Research Program, \\ Department of Pharmacology and the Mental Health Research Institute, \\ University of Michigan Medical Center, Ann Arbor, Mich. 48104, U.S.A.
}

(Received 17 July 1969; accepted 9 October 1969)

\begin{abstract}
The effect of hemicholinium (HC-3) on choline distribution was studied in vivo in the subcellular fractions of the canine caudate nucleus. Both $\mathrm{HC}-3$ and choline were given intraventricularly to locally anesthetized, decamethonium-paralyzed dogs maintained on artificial ventilation. At various time intervals after intraventricular injection of methyl-14 $\mathrm{C}$-choline alone and in various $\mathrm{HC}-3 /$ methyl ${ }^{-14} \mathrm{C}$-choline ratios, the animals were sacrificed by air embolus and the caudate was removed and subjected to subcellular fractionation. It was found that methyl- ${ }^{14} \mathrm{C}$-choline accumulated primarily in the microsomal (Mic) and the nerve ending, mitochondria, lysosome (NEML) fractions. There was greater accumulation at $4 \mathrm{hr}$ than at $1 \mathrm{hr}$. The combined injection of $\mathrm{HC}-3$ and methyl- ${ }^{14} \mathrm{C}$-choline in ratios of $10,100,500$ and 2500 progressively increased the uptake of choline by the subcellular elements; an extract of the watersoluble components of fraction NEML showed that $\mathrm{HC}-3$ reduced the conversion of choline to acetylcholine. On the other hand, HC-3 increased the labeling of phosphorylcholine and, particularly, of cytidine diphosphocholine. The levels of free choline in the caudate were not affected by: HC-3.
\end{abstract}

Although the role of acetylcholine as a neurotransmitter in the central nervous system is now widely recognized, ${ }^{1-3}$ not much is known about the metabolic origin of its choline moiety. Only recently has this topic received attention, ${ }^{4-12}$ and it is now clear that the synthesis of most of the choline does not occur in the brain, but rather, that choline is supplied to the brain from extracerebral sources such as the liver.

Most experiments in which the uptake of choline by the central nervous system was examined have used tissue slices. For example, Schuberth et al. ${ }^{5}$ examined the uptake of choline by mouse cortical slices; they concluded that, although choline entered the slice by an active transport mechanism, it was not "significantly metabolized by this tissue". More recently Chakrin and Shideman ${ }^{7}$ studied the conversion of methyl- ${ }^{3} \mathrm{H}-$ labeled choline to acetylcholine by cat cerebral cortex, while Browning and Schulman ${ }^{13}$ studied the use, for acetylcholine synthesis, of other possible precursors such as ethanolamine, methionine and serine as well as acetate or glucose. Choline uptake by isolated guinea pig cortex nerve endings has also been described. ${ }^{8}$

\footnotetext{
* A preliminary report was presented at the Federation Meetings in Atlantic City, April, 1969; Fedn Proc. 28, 292 (1969).

† Supported in part by U.S. Public Health Service Grants MH-11846 (E.F.D.) and NB-06294 (O.Z.S.).
} 
Hemicholinium-3 (a, $a^{\prime}$-dimethylethanolamino-3,4'-bis acetophenone; HC-3), ${ }^{14}$ an agent which interferes with the synthesis of acetylcholine in the nervous system has been widely used in studies of the relationship between the tissue uptake of choline and its conversion to acetylcholine (see, for example, references $11,15,16$ ). It has been shown that small doses $(10-100 \mu \mathrm{g}$ total) of HC-3, given intraventricularly to dogs, cause a marked lowering of acetylcholine levels, ${ }^{17}$ particularly in the caudate nucleus and the hippocampus. More recently, Sellinger et al. ${ }^{18}$ have reported that, after its intraventricular administration to dogs, HC-3 binds with a high affinity to synaptic membranes of the caudate nucleus and hippocampus. It has also been shown ${ }^{19}$ that the reduction of acetylcholine levels in rat brain elicited by intraventricular $\mathrm{HC}-3$ can be prevented if choline is administered simultaneously.

In order to relate our previous findings ${ }^{18}$ on the intracellular distribution of $\mathrm{HC}-3$ in the caudate nucleus to the accepted ability of the drug to interfere with the tissue uptake of choline, we have examined the latter process as it occurs in vivo in the caudate nucleus of the dog. The caudate nucleus was chosen because of its very high content of acetylcholine. The present paper reports on the uptake of choline by the subcellular components of this tissue, as well as on the initial steps in the metabolic disposition of the choline molecule. The influence on these processes, viz. uptake and metabolic disposition, of $\mathrm{HC}-3$ is also documented. The data indicate that choline uptake by the fractions containing the nerve endings, mitochondria and lysosomes (NEML) and the membranes of the endoplasmic reticulum (Mic) increased as a function of injection time (up to $4 \mathrm{hr}$ ). HC-3 decreased the conversion of labeled choline into acetylcholine and, surprisingly, increased the labeling of phosphorylcholine and of cytidine diphosphocholine.

\section{MATERIALS AND METHODS}

Chemicals. Hemicholinium bromide was obtained from the Aldrich Chemical Co. Its purity was checked by chromatography on Whatman no. 1 paper in a solvent system of $n$-butanol-glacial acetic acid-water $(4: 1: 2)$ using Dragendorff's reagent ${ }^{20}$ for its visualization. An $R_{f}$ value of 0.49 was obtained. $\mathrm{Me}-{ }^{14} \mathrm{C}$-choline chloride was from New England Nuclear $(7.6 \mathrm{mc} / \mathrm{m}$-mole) or Amersham-Searle $(54 \mathrm{mc} / \mathrm{m}-\mathrm{mole})$. Phosphorylcholine-1,2-14 $\mathrm{C}(9 \cdot 4 \mathrm{mc} / \mathrm{m}-\mathrm{mole})$ and cytidine diphosphocholine- $1,-2-{ }^{14} \mathrm{C}(0 \cdot 3$ $\mathrm{mc} / \mathrm{m}$-mole) were from Tracerlab. Me- ${ }^{14} \mathrm{C}$-acetylcholine chloride $(10.4 \mathrm{mc} / \mathrm{m}$-mole $)$ was from Nuclear Chicago. The purity of $\mathrm{Me}^{14} \mathrm{C}$-choline and its derivatives was determined by thin-layer chromatography as described below. Other chemicals used included acetylcholine (Aldrich), cytidine diphosphocholine (Sigma), choline chloride (Calbiochem) and phosphorylcholine (Ca salt; Mann).

Animals. Beagle-like mongrel dogs of either sex $(8-13 \mathrm{~kg})$ were used. They were anesthetized with $\mathrm{N}_{2} \mathrm{O}-\mathrm{O}_{2}(80: 20)$, paralyzed with decamethonium, intubated and artificially respired as described previously. 17,18 Both HC-3 and choline were injected into the left lateral ventricle. Sacrifice by intravenous air embolus and removal of the whole brain were made at 1 and $4 \mathrm{hr}$ after the intraventricular injection of 2, 10 or $100 \mu \mathrm{g} \mathrm{Me}-{ }^{14} \mathrm{C}$-choline. The caudate nucleus was dissected free and placed into a preweighed beaker containing ice-cold $0.25 \mathrm{M}$ sucrose and physostigmine salicylate, $5 \times 10^{-4} \mathrm{M}$.

Preparation of subcellular fractions. The caudate nucleus was homogenized in the sucrose-physostigmine solution with seven excursions of the Teflon-stainless pestle in 
a glass tube (A. H. Thomas Co., Philadelphia, Pa.; item no. 4288). The $5 \%(\mathrm{w} / \mathrm{v})$ homogenate was centrifuged at $800 \mathrm{~g}$ for $10 \mathrm{~min}$, yielding a pellet and a supernatant. The pellet was resuspended in the sucrose-physostigmine solution, homogenized and resedimented at $800 \mathrm{~g}$ for $8 \mathrm{~min}$. This was repeated once more, yielding the nuclear fraction $(\mathrm{N})$. The pooled supernatants were combined and centrifuged at $10,000 \mathrm{~g}$ for $15 \mathrm{~min}$. The pellet was washed, homogenized and centrifuged at $10,000 \mathrm{~g}$ for $12 \mathrm{~min}$ to yield the fraction containing nerve endings, mitochondria and lysosomes (fraction NEML). The supernatants from this fraction were combined and centrifuged at $100,000 \mathrm{~g}$ for $60 \mathrm{~min}$, yielding the microsomal fraction (Mic) and the soluble supernatant (S). All centrifugations were performed in a Spinco preparative centrifuge at $4^{\circ}$.

Choline assay. Free choline was determined by the method of Long et al., ${ }^{21}$ after separation from phosphorylcholine and cytidine diphosphocholine by the method of Ansell and Spanner. ${ }^{9}$ Tissue samples were removed and placed in a freezer $\left(-20^{\circ}\right)$ before assay.

Chromatographic procedures. Sucrose was removed from the water-soluble tissue extract ${ }^{22}$ by passage through a small $(1.0 \times 8 \mathrm{~cm})$ column of Rexyn-300 $(\mathrm{H}-\mathrm{OH}$; Fisher). Elution of the radioactive choline and metabolites was accomplished by washing the column with $80 \mathrm{ml}$ of $0.1 \mathrm{M} \mathrm{NH}_{4}$ acetate. Separation of choline, phosphorylcholine and cytidine diphosphocholine was by thin-layer chromatography (TLC) on cellulose powder MN-300 (Macherey, Magell Co.). The chromatograms were run at room temperature for a length of $12-15 \mathrm{~cm}$ in a solvent consisting of $n$-butanol-ethanol-acetic acid-water $(8: 2: 1: 3)$. For optimal separation of phosphorylcholine and cytidine diphosphocholine, the chromatogram was run twice with the same solvent. The separation achieved is illustrated in Fig. 2. C21-standards were used to identify the location of each ${ }^{14} \mathrm{C}$-compound on the TLC plate. The dry plates were exposed to iodine vapors for visualization of the spots, which were marked, scraped off and transferred to scintillation vials. The iodine color was bleached by adding 0.1 $\mathrm{ml}$ of $2 \% \mathrm{NaHSO}_{3}$ to each vial. Water $(0.5 \mathrm{ml})$ was also added to facilitate the elution of the compounds from the cellulose. The scintillation mixture (see below) contained $10 \%(\mathrm{v} / \mathrm{v})$ of Biosolv-3 (Beckman).

Autoradiograms were made on Kodak X-ray film (Type AA-54) and were developed in Supermix (General Electric).

Radioactivity procedures. The radioactivity was measured in a Beckman liquid scintillation spectrometer (LS-200). The internal standard method was used to correct for quenching. Aliquots $(0 \cdot 3 \mathrm{ml})$ of the subcellular fractions were solubilized in NCS (Nuclear Chicago) and $15 \mathrm{ml}$ of a scintillation mixture consisting of toluene (1 liter), 2,5-diphenyloxazole $(5 \mathrm{~g})$ and 1,4-bis-2-(4-methyl-5-phenyloxazolyl)benzene $(0 \cdot 1 \mathrm{~g})$ was then added.

\section{RESULTS}

Lack of effect of intraventricular $H C-3$ on free choline levels

Free choline in the canine caudate nucleus was determined in eight animals. The mean choline level \pm S.D. was $1.36 \pm 0.28 \mu$ moles $/ \mathrm{g}$ of tissue. One $\mathrm{hr}$ or $4 \mathrm{hr}$ after HC-3 (5.0 mg, intraventricularly), the mean of the choline levels in six animals was closely similar, $1.52 \pm 0.10 \mu$ moles/g. There was therefore no significant difference $(\mathrm{P}>0.5)$ between the levels of choline in the control and the HC-3-treated animals, in contrast to the marked decrease in acetylcholine levels which this drug is known to elicit. 
Effect of time and dose on the intracellular distribution of choline radioactivity

After the injection of 2, 10 or $100 \mu \mathrm{g} \mathrm{Me}-{ }^{14} \mathrm{C}$-choline, the absolute levels of radioactivity in the subcellular fractions at $4 \mathrm{hr}$ were much higher than those present at $1 \mathrm{hr}$.

TABLE 1. DistRIBUTION OF RADIOACTIVITY IN SUBCELLULAR FRACTIONS OF THE CAUDATE NUCLEUS AFTER THE ADMINISTRATION OF Me-14C-CHOLINE*

\begin{tabular}{|c|c|c|c|c|c|}
\hline \multirow{2}{*}{$\begin{array}{l}\text { Dose of } \mathrm{i} \text {. vent. } \\
\text { choline } \\
(\mu \mathrm{g})\end{array}$} & \multirow[b]{2}{*}{ n } & \multirow{2}{*}{$\begin{array}{l}\text { Sacrifice } \\
\text { time } \\
\text { (hr) }\end{array}$} & \multicolumn{3}{|c|}{$\begin{array}{l}\text { Per cent of total recovered } \\
\text { radioactivity } \\
\text { (dpm/g) }\end{array}$} \\
\hline & & & NEML & Mic & $\mathrm{S}$ \\
\hline 2 & 3 & $\begin{array}{l}1 \\
4\end{array}$ & $\begin{array}{l}17.2 \pm 0.8 \\
25.8+1.4\end{array}$ & $\begin{array}{l}11.9 \pm 1.8 \\
22.2 \div 3.8\end{array}$ & $\begin{array}{l}68 \cdot 0+2 \cdot 0 \\
44 \cdot 3+3 \cdot 0\end{array}$ \\
\hline 10 & 3 & $\frac{1}{4}$ & $\begin{array}{l}13.9 \\
27.7 \\
27.4\end{array}$ & $\begin{array}{l}13.5+0.1 \\
18.8+1.6\end{array}$ & $\begin{array}{l}69 \cdot 6+1 \cdot 1 \\
42 \cdot 3-2 \cdot 2 \cdot 2\end{array}$ \\
\hline 100 & 2 & $\begin{array}{l}1 \\
4\end{array}$ & $\begin{array}{l}14 \cdot 1 ; 15 \cdot 2 \\
26 \cdot 8 ; 28 \cdot 0\end{array}$ & $\begin{array}{l}13 \cdot 8 ; 17.0 \\
19 \cdot 5 ; 22.9\end{array}$ & $\begin{array}{l}65.0 ; 70.2 \\
46 \cdot 2 ; 49.4\end{array}$ \\
\hline
\end{tabular}

* Intraventricular = i. vent.; number of animals =- $n$; NEML = nerve endings, mitochondria, lysosomes; Mic = membranes of the endoplasmic reticulum + ribosomes; $\mathrm{S}=$ soluble fraction, isolated according to de Robertis et al. ${ }^{23}$

$\uparrow$ Means \pm S.D. for $n=3$ are given; for $n=2$, the individual values are listed.

[TN $\square$ NLML RIC $\square$ SOUELE

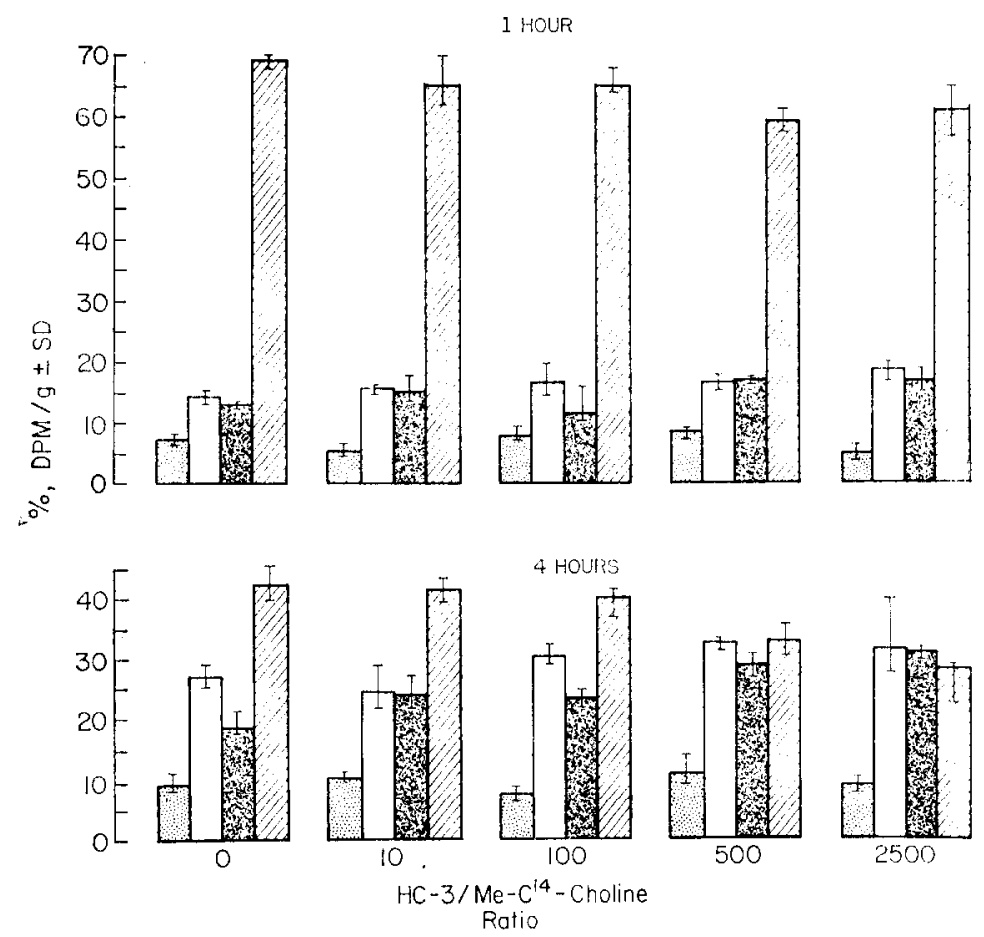

Fig. 1. Effect of $\mathrm{HC}-3$ onmethyl- ${ }^{14} \mathrm{C}$-choline radioactivity distribution in the subcellular fractions of the dog caudate nucleus. The $y$-axis represents the per cent of the total dpm/g $上$ S.D. in the fraction and the $\mathrm{x}$-axis the ratio: $\mathrm{HC}-3 / \mathrm{Me}-{ }^{14} \mathrm{C}$-choline. The dose of choline was $10,10,10,10$ and $2 \mu \mathrm{g}$, whilc that of $\mathrm{HC}-3$ was $0,100,1000,5000$ and 5000 . Three animals were used for each dose ratio, except for the ratio of 100 (only two animals). Animals were sacrificed at 1 and $4 \mathrm{hr}$. See text for details. 


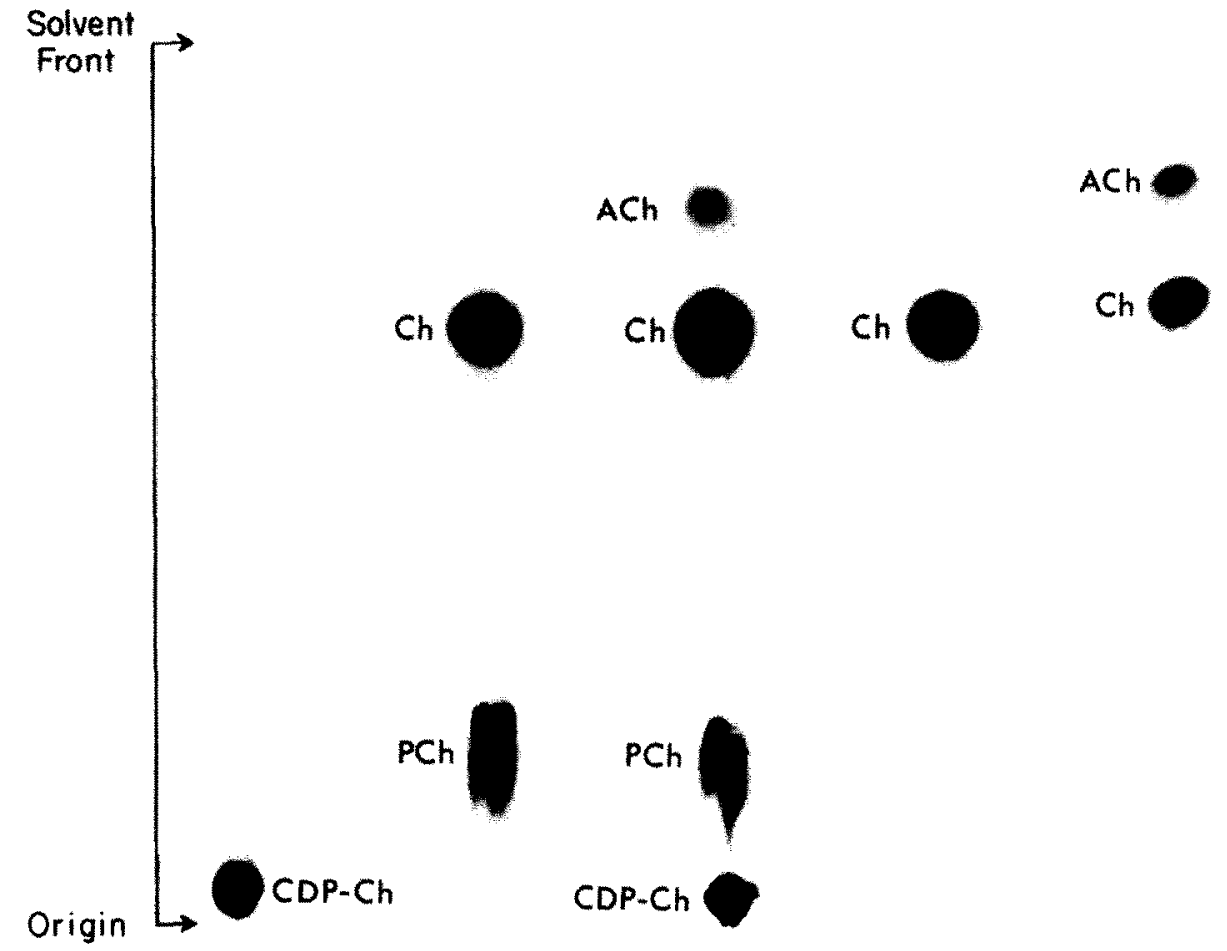

Frg. 2. Autoradiogram of separated mixture of choline, acetylcholine, phosphorylcholine and cytidine diphosphocholine. ACh, acetylcholine; Ch, choline; PC, phosphorylcholine; CDP-Ch, cytidine diphosphocholine. 
As indicated in Table 1, the percentage uptake into the NEML fraction was somewhat greater than that into the Mic fraction at $4 \mathrm{hr}$, while the percentage of radioactivity in the soluble portion (fraction S) did not appreciably change from 1 to $4 \mathrm{hr}$ with the different doses of choline. This dose independence of the distribution of the radioactivity was also shown by the particulate fractions.

Effect of increasing ratios of hemicholinium to choline on the intracellular distribution of $\mathrm{Me}^{-14} \mathrm{C}$-choline

As shown in the upper part of Fig. 1, increasing the ratio of $\mathrm{HC}-3 / \mathrm{Me}-{ }^{14} \mathrm{C}$-choline from 0 to 2500 had no effect on the distribution of radioactivity in the four major subcellular fractions $1 \mathrm{hr}$ after their simultaneous intraventricular injection. However, $4 \mathrm{hr}$ after $\mathrm{HC}-3$ plus choline, the percentage of the total radioactivity in fractions NEML and Mic had increased, the increase being greatest in the latter fraction (from $18 \%$ with no HC-3 to $32 \%$ at the highest HC-3 to choline ratio). There was a corresponding decrease of radioactivity in the soluble fraction $\mathrm{S}$, suggesting a facilitating effect of $\mathrm{HC}-3$ on the uptake of choline by the particulate fractions, NEML and Mic. However, there was no change in the percentage of radioactivity in the nuclear $(\mathrm{N})$ fraction as a function of the $\mathrm{HC}-3$ to choline ratio, although, in absolute values, the incorporation of radioactivity into this fraction was also somewhat higher at $4 \mathrm{hr}$ than at $1 \mathrm{hr}$ postinjection.

\section{Effect of $\mathrm{HC}-3$ pretreatment on the intracellular distribution of $\mathrm{Me}-{ }^{14} \mathrm{C}$-choline}

When choline was given alone, the highest percentage of radioactivity was found in the soluble fraction (S) both at 1 and $4 \mathrm{hr}$ (Table 2). However, this fraction showed a decrease in radioactivity at $4 \mathrm{hr}$ compared to $1 \mathrm{hr}$ which was counterbalanced by a corresponding increase in the particulate fractions $(\mathrm{N}, \mathrm{NEML}$ and Mic; Table 2). The simultaneous administration of $\mathrm{HC}-3(5 \mathrm{mg})$ and $\mathrm{Me}^{-14} \mathrm{C}$-choline $(2 \mu \mathrm{g})$ resulted in a moderate increase in the uptake of choline by the Mic fraction at $1 \mathrm{hr}$ as compared to when choline was given alone. However, at $4 \mathrm{hr}$, there was a much greater decrease in the water-soluble radioactivity in fraction $\mathrm{S}$ and a correspondingly high increase of

TABLe 2. EfFect of HC-3 PRetreatment on the distribution of Me- ${ }^{14}$ C-Choline RADIOACTIVITY IN THE SUBCELLULAR FRACTIONS OF THE CAUDATE NUCLEUS"*

\begin{tabular}{|c|c|c|c|c|c|c|}
\hline \multirow[b]{2}{*}{ Pretreatment } & \multirow{2}{*}{$\begin{array}{l}\text { No. of } \\
\text { animals } \\
\text { (n) }\end{array}$} & \multirow{2}{*}{$\begin{array}{l}\text { Time of } \\
\text { sacrifice } \\
\text { (hr) }\end{array}$} & \multicolumn{4}{|c|}{$\begin{array}{c}\text { Per cent of total recovered radioactivity } \dagger \\
(\mathrm{dpm} / \mathrm{g})\end{array}$} \\
\hline & & & $N$ & NEML & Mic & $S$ \\
\hline 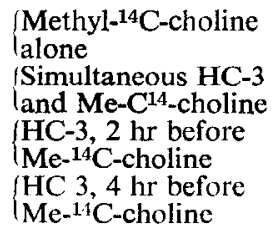 & $\begin{array}{l}3 \\
4 \\
5 \\
4 \\
2 \\
2 \\
1 \\
1\end{array}$ & $\begin{array}{l}1 \\
4 \\
1 \\
4 \\
1 \\
4 \\
1 \\
4\end{array}$ & $\begin{array}{l}2 \cdot 8 \pm 0 \cdot 96 \\
7 \cdot 9 \pm 1 \cdot 72 \\
5 \cdot 4 \pm 2 \cdot 4 \\
9 \cdot 8 \pm 3 \cdot 2 \\
5 \cdot 7 ; 8 \cdot 9 \\
10 \cdot 2 ; 10 \cdot 4 \\
7 \cdot 6 \\
15 \cdot 1\end{array}$ & $\begin{array}{l}17 \cdot 2 \pm 0 \cdot 75 \\
25 \cdot 8 \pm 1 \cdot 4 \\
17 \cdot 3 \pm 1 \cdot 85 \\
34 \cdot 1 \pm 5 \cdot 7 \\
16 \cdot 3 ; 18 \cdot 3 \\
32 \cdot 0 ; 25 \cdot 0 \\
22 \cdot 4 \\
22 \cdot 5\end{array}$ & $\begin{array}{l}12 \cdot 0 \pm 1 \cdot 8 \\
22 \cdot 0 \pm 3 \cdot 8 \\
17 \cdot 0 \pm 2 \cdot 3 \\
30 \cdot 0 \pm 3 \cdot 0 \\
11 \cdot 0 ; 11 \cdot 8 \\
31 \cdot 8 ; 30 \cdot 0 \\
15 \cdot 3 \\
22 \cdot 6\end{array}$ & $\begin{array}{l}68 \cdot 0 \div 2 \cdot 0 \\
44 \cdot 3 \pm 3 \cdot 0 \\
60 \cdot 3 \pm 4 \cdot 5 \\
27 \cdot 1 \pm 4 \cdot 9 \\
67 \cdot 0 ; 61 \cdot 0 \\
26 \cdot 0 ; 34 \cdot 6 \\
54 \cdot 7 \\
39 \cdot 8\end{array}$ \\
\hline
\end{tabular}

${ }^{*}$ Methyl. ${ }^{14} \mathrm{C}$-choline was injected intraventricularly along with $\mathrm{HC} 3$, as noted. The specific activity of the labeled choline was $7.6 \mathrm{mc} / \mathrm{m}$ mole. Total volume of each injection was $0.2 \mathrm{ml}$. The injected doses: $\mathrm{HC}-3,5 \mathrm{mg}$; Me-14 C-choline, $2 \mu \mathrm{g}$. See Table 1 for abbreviations. $\mathrm{N}=$ nuclei

$\dagger$ For $\mathrm{n}=3,4$ or 5 , means \pm S.D. are given; for $\mathrm{n}=2$, individual values are given. 
the radioactivity in the particulate fractions, especially fraction NEML. When compared with the control animals who received choline alone, a 2-hr pretreatment with $\mathrm{HC}-3$ did not seem to affect the distribution of choline radioactivity $1 \mathrm{hr}$ after choline injection. Four $\mathrm{hr}$ after choline injection, there was an increase in the Mic fraction $(30.4 \%)$ as compared to $4 \mathrm{hr}$ after choline alone $(22.0 \%)$. A 4 -hr pretreatment with $\mathrm{HC}-3 \mathrm{had}$ no effect on the distribution of radioactivity when tested $4 \mathrm{hr}$ after choline. However, $1 \mathrm{hr}$ after choline, an increase in the uptake of radioactivity in both particulate fractions could be discerned; it was grealer in fraction NEML $(22.4 \% \mathrm{vs}$. $17.3 \%)$ than in fraction Mic (15.3 vs. $12.0 \%)$.

\section{Effect of HC-3 on the distribution of water-soluble choline metabolites}

The water-soluble metabolites of choline, namely cytidine diphosphocholine (CDP-Ch), phosphorylcholine (PC) and acetylcholine (ACh) were separated from choline by TLC. Figure 2 shows a model autoradiogram of the separated labeled standards. For identification of the radioactive tissue choline metabolites, they were co-chromatographed with authentic ${ }^{12} \mathrm{C}$-standards which were visualized by suitable spray reagents for choline derivatives, ${ }^{20}$ phosphorus or by ultraviolet fluorescence. The effect of increasing the ratio $\mathrm{HC}-3 / \mathrm{Me}^{14} \mathrm{C}$-choline on the distribution of the water-soluble choline metabolites in fractions NEML and $\mathrm{S}$ is shown in Fig. 3. A ratio of 500 reduced the $\mathrm{ACh}$ in the NEML fraction as expected. No labeled $\mathrm{ACh}$

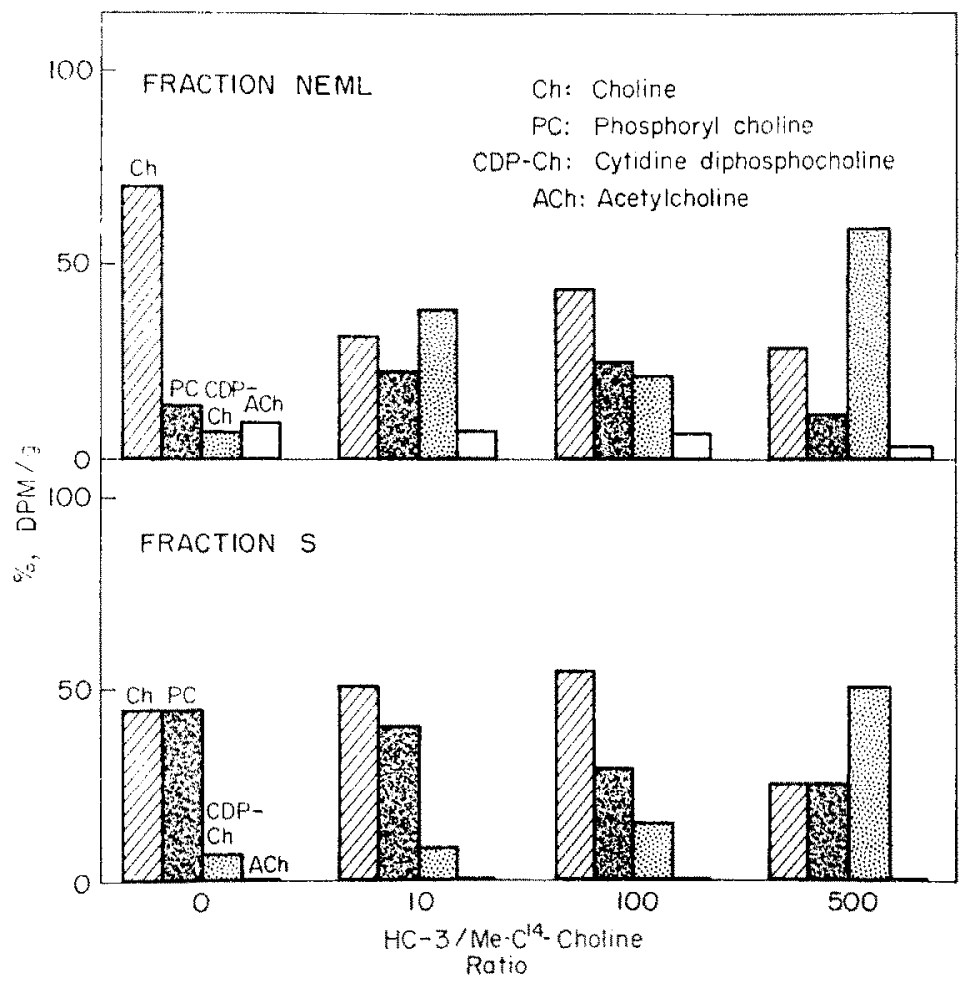

FIG. 3. Effect of $\mathrm{HC}-3$ on the formation of water-soluble metabolites of choline. The animals were sacrificed $1 \mathrm{hr}$ after the simultaneous intraventricular injection of $\mathrm{HC}-3$ and choline. Details are the same as in Fig. 1, except that the $\mathrm{HC}-3 / \mathrm{Me}-{ }^{14} \mathrm{C}$-choline ratio of 2500 was omitted. 
was found in fraction $\mathrm{S}$ under the conditions of these experiments, in spite of the presence of $5 \times 10^{-4} \mathrm{M}$ physostigmine to prevent $\mathrm{ACh}$ hydrolysis. Free choline decreased in fraction NEML with increasing HC-3/choline ratios, while phosphorylcholine tended to increase in the NEML and decrease in the S fraction. Particularly noteworthy, however, was the increase of CDP-Ch in fraction NEML at the highest $\mathrm{HC}-3 / \mathrm{Me}-{ }^{-14} \mathrm{C}$-choline ratio.

\section{DISCUSSION}

This investigation shows that the dog caudate nucleus accumulates radioactivity injected as $\mathrm{Me}^{-14} \mathrm{C}$-choline. Since our data indicate that the free choline content of the caudate is $1.35 \mu$ moles $/ \mathrm{g}$ of tissue, a concentration of less than $0 \cdot 1 \mu$ mole choline injected into the ventricle would not be expected to reach the caudate without an active transport mechanism. Yet, direct evidence that choline actively concentrates in the caudate from the cerebrospinal fluid is lacking and Ansell and Spanner ${ }^{9}$ have suggested that, instead, the liver is the major source of cerebral choline.

The accumulation of radioactivity was significant in subcellular fractions, NEML and Mic. In mouse brain slices, Schuberth et al..$^{5}$ demonstrated that choline is concentrated in nerve endings and mitochondria, while Marchbanks 8 suggested that cerebral mitochondria take up choline with approximately the same kinetics as do nerve endings.

Sellinger et al. ${ }^{18}$ studied the distribution of ${ }^{14} \mathrm{C}-\mathrm{HC}-3$ among the subcellular fractions of the canine caudate nucleus. They found that the NEML fraction had a greater ability to concentrate $\mathrm{HC}-3$ than the other fractions studied. At $4 \mathrm{hr}$ after the administration of ${ }^{14} \mathrm{C}-\mathrm{HC}-3,61$ per cent of the tissue radioactivity was found in this fraction. In the present experiments, choline radioactivity was also appreciable in this fraction, but amounted to only about 30 per cent of the total tissue radioactivity. This suggests a difference in the rate of intracellular flux for the two compounds, choline and $\mathrm{HC}-3$.

To our knowledge there are no previous data on the uptake of choline by brain microsomes. This fraction showed a definite choline accumulation both alone and after HC-3 pretreatment (Table 2). Since this uptake may be related to the fact that both microsomes and mitochondria can synthesize phospholipids, ${ }^{24}$ it is likely that some of the radioactive choline was made into phospholipids within the membraneladen NEML and Mic fractions. Evidence for this contention as well as the demonstration of an activating effect of $\mathrm{HC}-3$ on this overall process is presented elsewhere.*

The data obtained shed no light on the effect of $\mathrm{HC}-3$ on the mechanism of the tissue uptake of choline, but only on its intracellular metabolic disposition. It is interesting that, heretofore, most investigators have studied only the effect of HC-3 on the conversion of choline to acetylcholine ${ }^{4}$ and only a few on its conversion to phosphorylcholine. ${ }^{10,25}$ Only Hebb et al., ${ }^{4}$ to our knowledge, mentioned the presence of a great deal of the injected choline radioactivity in the alcoholic extracts of the caudate nucleus, yet they failed to explore its presumable lipid naturc. The present study, in which such an exploration was made, has revealed that HC-3 accelerates the metabolic utilization in vivo of cerebral choline along the quantitatively dominant pathway of lipid formation via cytidine diphosphocholine. ${ }^{9}$

* M. V. Gomez, E. F. Domino and O. Z. Sellinger, submitted for publication. 


\section{REFERENCES}

1. W. Feldberg, J. Physiol., Lond. 103, 367 (1945).

2. G. B. KollLE (Ed.), Cholinesterase and Anticholinesterase Agents, pp. 1-1220, Springer, New York (1963).

3. Z. Votava, Ann. Rev. Pharmac. 7, 223 (1967).

4. C. O. Hebe, G. M. Ling, E. G. MCGeer, P. L. McGeer and D. Perkins, Nuture, Loml. 204, 1309 (1964).

5. J. Schuberth, A. Sundwall, B. Sorbo and J. O. Lindell, J. Neurochem. 13, 347 (1966).

6. G. B. ANSELl and S. SPANNER, J. Neurochem. 14, 873 (1967).

7. L. W. Chakrin and F. E. Shideman, Int. J. Neuropharmac. 7, 337 (1968).

8. R. M. Marchbanks, Biochem. J. 110, 533 (1968).

9. G. B. ANSetl and S. SpanNer, Biochem. J. 110, 201 (1968).

10. B. Collier and C. Lano, Can. J. Physiol. Pharmac. 47, 119 (1969),

11. B. Collier and F. C. Macintosh, Can. J. Physiol. Pharmac. 47, 127 (1969).

12. J. Schuberth, B. Sparf and A. Sundwall, J. Neurochem. 16, 695 (1969).

13. E. T. Browning and M. P. Schulman, $f$. Neurochem. 15, 1391 (1968).

14. F. W. Schueler, J. Pharmac. exp. Ther. 115, 127 (1955).

15. J. E. Gardiner and F. R. Domer, Archs int. Pharmacodyn. Ther. 175, 482 (1968).

16. S. P. Bhatnagar, A. Lam and J. D. McColl, Biochem. Pharmac. 14, 421 (1965).

17. A. T. Dren and E. F. Domino, J. Pharmac. exp. Ther. 161, 141 (1968).

18. O. Z. Sellinger, E. F. Domino, V. B. Haarstad and M. E. Mohrman, J. Pharmac. exp. Ther. 167. 63 (1969).

19. P. Slater, Int. J. Neltroplamac. 7, $421(1968)$.

20. D. WALD, in Thin-Layer Chromatography. A Laboratory Hamdbook (Ed. E. SrAHL), pp. 483502. Academic Press, New York (1965).

21. C. Long, R. Odavić and E. J. SARGent, Biochem. J. 102, 216 (1967).

22. J. Crossland and A. Merrick, Nature, Lond. 171, 267 (1953).

23. E. de Robertis, A. Pellegirino de Iraldi, G. Rodriguez de Lores Arnalz and L. Salcianicoff, J. Netrochen. 9, 23 (1962).

24. G. F. Wilgram and E. P. Kennedy, J. biol. Chem. 238, 2615 (1963).

25. C. A. Robinson, J. R. Dayis and F. de Balbian Verster, Fedn Proc. 28, 292 (1969). 